\title{
Rediscovery and Characterization of Citrus Indica Tanaka, A Wild Endangered and Progenitor Species in Dailong Forest, Manipur, and Recommendations for Its Conservation.
}

\section{Elangbam Julia Devi}

Institute of Bioresources and Sustainable Development

Rajendra Kumar Labala

Institute of Bioresources and Sustainable Development

Rakesh Sanabam

Institute of Bioresources and Sustainable Development

Nandeibam Samarjit Singh

Institute of Bioresources and Sustainable Development

Rahul Modak

Kalinga Institute of Industrial Technology

Huidrom Sunitibala Devi ( $\square$ sunitibala.ibsd@nic.in )

Institute of Bioresources and Sustainable Development (IBSD)

\section{Short Report}

Keywords: Biodiversity Conservation, Citrus indica, Dailong forest, North East India

Posted Date: February 16th, 2021

DOI: https://doi.org/10.21203/rs.3.rs-191171/v1

License: (c) (i) This work is licensed under a Creative Commons Attribution 4.0 International License.

Read Full License 


\section{Abstract}

Citrus indica Tanaka is a wild endangered and one of the progenitor species of citrus endemic to North East (NE) India, which is reported in Nokrek Biosphere Reserve in the Garo hills of Meghalaya. A wild orange morphologically claimed to be $C$. indica was encountered in the Dailong forest of Tamenglong district, Manipur which is located in the Indo-Burma biodiversity hotspot region. Surveys were conducted to establish the exact identity of possible $C$. indica and study the natural habitat in Dailong forest area. The traditional morpho-taxonomic description for the identification of the plant is performed along with the molecular characterization using three chloroplast regions (trnL-F, psbK-I, matK-5'trnK spacer) and one nuclear (ITS) region. Phylogenetic analysis revealed that the $C$. indica found in Dailong Forest is monophyletic with the earlier reported $C$. indica sequence from Garo hills, Meghalaya. Both morphological and molecular data support the identity of $C$. indica that has been collected from Manipur. However, lack of knowledge and clearing of forest cover has led to an urgent need for the implementation of conservation strategies to safeguard this endangered species. This study supports the evidence that $\mathrm{NE}$ India is one of the origin centres for citrus and this finding can guide the conservationists to initiate priority for adopting possible methods of proper conservation of $C$. indica in the region.

\section{Introduction}

Citrus indica Tanaka belongs to the genus Citrus of the family Rutaceae and subfamily Aurantiodeae which was first discovered and characterized by Tanaka (1928). It is believed to be the most primitive and progenitor of all citrus species and is endemic to NE India (Singh 1981). Presently, it is reported to be endemic to the Tura range of Garo Hills of Meghalaya (Singh and Singh 2003) and the Garo tribes used the fruits of $C$. indica for medicinal and religious purposes (Malik et al. 2006). As the natural population of $C$. indica got drastically decreased due to large scale deforestation, Citrus Gene Sanctuary was established in the Nokrek Biosphere Reserve to protect the area (Singh 1981). Conservation of this species is required as it is endemic to only a specific region with a particular microclimate. Citrus genetic resources of NE India need appropriate conservation strategies as the wild and indigenous population is being eroded due to various anthropogenic activities like jhumming and introduction of exotic species, etc. $C$. indica is not only exposed to habitat destruction but also has extremely low genetic diversity, high habitat specificity, and low regeneration which pose a serious threat in its natural population (Kumar et al. 2010). Previously, besides Garo hills, $C$. indica was reported to be found wild in Naga hills of Nagaland, Manipur, and Kaziranga Reserve forest in Assam (Tanaka 1937; Singh 1981; Sharma et al. 2004). However, Singh and Singh (2003) reported the presence of this species only in Garo hills of Meghalaya which fall under the Nokhrek biosphere reserve. Thus, $C$. indica is one of the seven citruses in India which is enlisted as endangered as per IUCN norms (Singh and Singh 2003; Malik et al. 2006). Though, a recent study in Behali Reserve Forest of Assam recorded the occurrence of few $C$. indica species (Borah et al. 2018).

NE India has a rich biodiversity of citrus germplasm including 23 taxa and 68 varieties and it is gifted with highly favorable agro-climatic conditions for the growth of citrus (Sharma et al. 2004). 33 members 
of citrus have been enlisted in the digital database on the citrus biodiversity of Manipur (Sanabam et al. 2012). Bhattacharya and Dutta (1956) reported 17 species, 52 cultivars, and 7 probable natural hybrids of citrus are found growing in natural wild conditions in the NE India region. Many citrus species and progenitors are believed to have originated in this region (Malik et al. 2012). In a study to trace the proposed origin of citrus and its ancient dispersal routes, it was found that the ancestral citrus species are migrated originally from NE India, northern Myanmar, and north-western Yunnan (Wu et al. 2018). Thus, the NE India region is considered to be one of the centres of origin of citrus. However, citrus germplasm of NE India has been minimally utilized in the improvement programs due to a lack of exploration and characterization (Sharma et al. 2004). An approach for systematic exploration, characterization, and conservation of $C$. indica is still lacking (Malik et al. 2006). Systematic characterization including morphological and molecular identification should be implemented to assess the conservation and management policy of such rare and wild species. Molecular identification in higher plants has now become far simpler with the advent of various molecular markers and plant barcoding genes. The nuclear and chloroplast region had been extensively used as genetic markers for molecular taxonomic studies and plant identification (Yang et al. 2017). Since morphological characterization sometimes creates confusion in the identification of citrus taxonomy, implementation of appropriate molecular approaches have now been encouraged like molecular markers (Kumar et al. 2013), analysis of non-coding chloroplast DNA regions (Araujo et al. 2003; Chase et al. 1999; Lu et al. 2011; Morton et al. 2003) and ITS region (Hynniewta et al. 2014; Kyndt et al. 2010; Pessina et al. 2011; Xu et al. 2006). There are few previous studies in which $C$. indica is involved in the molecular phylogeny analysis like using RFLP and RAPD (Federici et al. 1998), RAPD, SCAR and cpDNA markers (Nicolosi et al. 2000), chloroplast DNA (Bayer et al. 2009; Jena et al. 2009), nuclear DNA (Kumar et al. 2013) and ISSR polymorphism (Kumar et al. 2010). These previous findings paved the way for taxon sampling in the phylogeny analysis for the present study.

Dailong is located in Tamenglong district of Manipur, North East India (NE India) which is part of the IndoBurma biodiversity hotspot region. Tamenglong is the least densely populated district of Manipur which has a forest cover of $88 \%$. Dailong forest covers an area of $11.35 \mathrm{~km} 2$. In May 2017, the Government of Manipur declared Dailong village as the 'Biodiversity Heritage Site' under the Biological Diversity Act, 2002 Sect. 37(1) because of its rich biodiversity of flora and fauna. This village is home to the Rongmei Naga tribes of Tamenglong district. Even though there was an earlier report of the occurrence of $C$. indica in Manipur (Tanaka 1937; Singh 1981; Sharma et al. 2004), systematic efforts for characterization and conservation status has not been carried out in detail. The present study attempts to analyse the distribution, characterization and conservation of $C$. indica along with its associated local indigenous knowledge. Both the morphological and molecular analyses were employed to characterize the species as proper identification of species is fundamental for biodiversity conservation.

\section{Methods}

\subsection{Survey and morphological characterization}


During the surveys undertaken for citrus germplasm collection and citrus greening disease in Tamenglong district of Manipur, few patches of a type of wild citrus (suspected to be Indian wild orange or Citrus indica) were encountered in a moist tract of Dailong forest. Further exploration was continued from 9th to 13th April 2018 to record the presence of any other population inside the forest. Information was collected from people who dwelled near the forests and subsequently two other sites were detected inside the forest (Table 1). A possible threat associated with the natural habitat and conservation issues had been analyzed through interaction with the community of Dialong village. Indigenous and traditional information of the species was collected by interviews with the local tribes inhabiting the area.

Meteorological data of the natural habitat of this species was recorded to know the region's microclimate. Photographs of the plants were taken in its natural habitat area (Fig. 1). The coordinates and elevations of the locations were recorded using a GPS unit (Garmin) (Table 1). The survey was undertaken in such a manner that involved minimal disturbance and harm to the target plant and also the overall forest environment in Dailong area. General field observations along with the natural population were briefly analyzed. All the individual plants were critically studied to determine their correct taxonomic identity and treated as a representative specimen. Young leaf tissues and fruits from all the samples were immediately stored in silica gel for subsequent DNA isolation in the laboratory. One representative voucher specimen of the collected samples is authenticated, and stored in the herbarium of the Institute of Bioresources and Sustainable development (IBSD), Imphal with the herbarium accession number 263. Morphological characters of the citrus were recorded using 'Descriptors for citrus' by the International Plant Genetic Resources Institute (IPGRI) Rome, Italy. 14 quantitative and 27 qualitative characters were characterized (Table 2a and b).

\subsection{Molecular characterization 2.3.1. DNA extraction and PCR}

The leaf samples were taken for total plant genomic DNA isolation. About $100 \mathrm{mg}$ of each sample was ground in liquid nitrogen using a pre-cooled mortar and pestle. Total DNA extraction from this powdered tissue was further performed with the DNeasy Plant Mini Kit (Qiagen, Germany) by following the user's instructions. Nucleic acid was quantified by spectrophotometry (Nanodrop 2000, Thermo Scientific) and it is quality checked by electrophoresis on $0.8 \%$ agarose gel.

PCR amplification of three chloroplast regions (matK-5'trnK spacer, psbl-psbK, and trnL-F) and one nuclear region ITS (ITS1, 5.8S, and ITS2) was performed by using the respective primers (Table 3 ). The PCR reaction was performed in a C1000 Touch ${ }^{\text {TM }}$ Thermal cycler (Biorad) with $25 \mu \mathrm{L}$ reaction volume. The reaction mixture consists of 10X PCR buffer, 2-25 mM of $\mathrm{MgCl}_{2}, 5-20$ pmol of each primer, $0.125 \mathrm{mM}$ 1.25M for each dNTPs, 0.5-1U Taq DNA polymerase (Sigma- Aldrich), and genomic DNA of 10-50 ng. PCR profile followed for different primer pairs was given in Table 3. The PCR products obtained were electrophoresed in $1.2 \%$ agarose gel for 1 hour and 30 minutes at a constant volt of $60 \mathrm{~V}$.

\subsubsection{Sequencing and phylogenetic analysis}


The bands obtained were excised and eluted using Qia quick gel extraction kit (Qiagen) following the manufacturer's instructions. The eluted products were sent for direct sequencing at Bioserve Technologies, Hyderabad. Using BLAST analysis of the NCBI database (Altschul et al. 1997), the identity of sequences was confirmed. The consensus sequence of the four genomic regions (three chloroplast and one nuclear) was obtained using Bioedit software 7.05 (Hall, 1999). Closely related sequences were retrieved from GenBank database and used for the construction of phylogeny (Supplementary Table 1). Multiple alignments of sequences in this study and sequences from the GenBank database were performed with the ClustalW program incorporated in MEGA X (Kumar et al., 2018). One representative sequence of each of the marker sequences (i.e., four sequences) used in this study was annotated and deposited in the National Centre for Biotechnological Information (NCBI) GenBank database.

Phylogenetic analysis of the ITS, $\operatorname{trn} L-F, p s b K-p s b /$ and $m a t K-5$ 'trnK spacer regions were generated using the Maximum Likelihood method incorporated in the software IQ-TREE version 1.6.12 (Nguyen et al. 2015) with a bootstrap approximation of 1000 replicates. The final depiction of the tree was produced using FigTree version 1.4.3 (http://tree.bio.ed.ac.uk/software/figtree). Outgroup taxa were selected based on the analyses of Chase et al. (1999), Samuel et al. (2001), and Morton et al. (2003). Zanthoxylum monophyllum, Poncirus trifoliata, Atalantia monophylla, and Koelreuteria paniculata were chosen as outgroups.

\section{Results}

\subsection{Sampling and Morphological characterization:}

The Indian wild orange or $C$. indica was found distributed in Dailong village of Tamenglong district, Manipur (Fig. 2). C. indica is locally known as 'Garuan-thai' ('Garuan' means cane, 'thai' means fruit) among the Rongmei tribes. The word 'cane' is given because the fruit stem is woody, slender, flexible, and sometimes climber. From interactions with senior members of the community, it was learnt that the particular citrus specimen had a distinct local name. The existence of a local name further indicated that the particular genotype/specimen has been associated with the community for a long time. During the survey, a total of thirty-two specimens of wild $C$. indica were identified from three spots in the forest area of Dialong village (Table 1). In one spot, 20 specimens were recorded from, where $C$. indics is found maximally concentrated while the other two spots had a sparse and scattered occurrence. The type of plants varied from a thorny bush to a climber of 3 to 4 meters in height. Among the specimen, only five of them had a thick and bushy canopy and certainly bore fruit. Plants from the same spot were separated at least by 5 meters. The natural population associated with the wild orange in the forest includes Xanthoxyllum sp, Melocanna bambusoides, Melocanna baccifera, Castapnosis spp., Medusferrea sp, Albizzia spp., Phoebe hainesiana, Albizia lebbeck, Tectona grandis, Quercus spp., orchids species like Dendrobium sp, Vanda sp, and several edible wild mushrooms.

The village of Dailong enjoyed high rainfall conditions of $3,135 \mathrm{~mm}$ with humidity of $76 \%$ and average temperature ranging from 4 to $31^{\circ} \mathrm{C}$ (Directorate of Environment \& Climate Change, Govt of Manipur). 
Preference for a unique shady microclimate comes to light as all the three locations come within the canopy of tall and dense forest plants. Morphological observation of the specimens does not reveal any distinctive character among them. However, variation in their habitat is quite significant in that some were small bushy shrubs, others straight tall to climbers type with spread canopy. Despite existing in wild conditions, the citrus plants were relatively free from any symptoms of disease.

The quantitative and qualitative morphological characters of fruit, leaf, and seed were recorded (Fig. 3) and given in Table 2a and $b$ respectively. Fruits were obloid which weighed ranging from 21.60 to 30.71 $\mathrm{gm}$. The fruit rind is whitish with a thickness of 0.17 to $0.25 \mathrm{~cm}$. The outer dark orange fruit skin was smooth and shiny consisting of conspicuous oil glands with density 34.30 to $44.23 \mathrm{~cm}^{2}$. The number of fruit segments ranges from 9.00 to 10.00. Leaf division is simple with elliptic lamina length 8.35 to 12.00 $\mathrm{cm}$, tapering at both ends. Seeds are ovoid, smooth, and creamish ranging from 7.00 to 10.00 per fruit. They are monoembryonic with green cotyledon and brown chalazal spot color.

\subsection{Molecular Characterization}

The four regions (three chloroplast and one nuclear) of citrus were utilized to confirm the taxonomic identity of the Indian wild orange 'Garuanthai' and also inferred their phylogenetic affinities to related taxa. Using the four pairs of primers for the three chloroplast sequences $p s b K-p s b /$ intergenic sequence, trn $L-F$ intergenic spacer region, matK $-5^{\prime}$ trnK spacer region, and one nuclear region ITS region, we obtained sequences from multiple samples from the three locations. The sequence alignment revealed sequence identity in all of the samples $(n=32)$. Based on the sequence analysis for each marker genes, all the specimens collected were identical. So, only one representative sequence was taken for each gene to annotate and submit in the NCBI GenBank with accession numbers KY963832, MN447519, MN443629, and MT782064 and further used for phylogenetic analysis. The phylogenetic analysis revealed that the sequence of 'Garuanthai' grouped with the $C$. indica in all the Maximum Likelihood trees consistently with all the four sequences (Fig. 4a, b, c, and d), thereby confirming the species to be $C$. indica. Zanthoxylum monophyllum, Poncirus trifoliata, Atalantia monophylla and Koelreuteria paniculata remained as outgroups in the respective phylogenetic trees in which they are incorporated.

\section{Discussion}

\subsection{Sites and morphological characterization}

A recent survey to Dailong Forest Tamenglong district reported the natural wild population of $C$. indica, locally known as 'Garuanthai' among the Rongmei tribes. In Fig. 2, the collection site of the $C$. indica in the present study is shown in the red triangle while the sites of earlier explorations are depicted in red circle. Among the earlier exploration, the presence of the species were recorded only in the Garo hills of Meghalaya (Singh and Singh 2003). Our present study reports the re-occurrence of this species in Manipur in Tamenglong District where it was said to be found in earlier studies. Such findings show that detailed research and studies should be carried out in various parts of NE India which remain largely unexplored because of its inaccessibility and difficult topographic nature. The meteorological data of 
Dailong forest area also support the microclimate of $C$. indica with low temperature, high rainfall, and humidity which is similar to that of the specific microclimate of Garo hills, which may be the probable reason for occurrence of the plants in this forest.

Morphological characterization of citrus often creates confusion among the taxonomists as there are innumerable hybrids and mutants of citrus due to frequent hybridization, mutation, and polyploidy among the citrus species throughout the world (Susheel Kumar et al. 2013). In the present study, the morphological characters are characterized based on the Descriptors for citrus (IPGRI 1999) protocol which is a standardized tool for the characterization system. In earlier works, morphological classification has relied on a combination of few characters of leaf, seed, flower, and fruit (Swingle 1943; Tanaka 1954; Tanaka 1977; Bhattacharya and Dutta 1956; Hodgson 1965; Swingle and Reece 1967; Singh 1967; Singh and Nath 1969). In the present survey, all the $C$. indica species observed have identical morphology except for the height and nature of the plants viz., bushy or climber, tall or stunted. The tallest plants were found in Jhoulangpang area of the forest, where the density of the plant is more compared to other locations where the plants are stunted. Potential causes for the differences may be variations in the age of the plants as the forest area was used for jhum cultivation till 1978 except the Joulangpang area. Maybe the plants were newly regenerated from seeds or stem and started acclimatizing in the area. Most of the plants were found in shady and moist slopes under the canopy of the forest. Kumar et al. 2010 observed that the plants preferred cool and shady places under the canopy of other trees. The quantitative and qualitative characterization of leaf, seed, and fruit samples showed that the characters of $C$. indica described in the present study are more or less similar with the characters of the species found in Garo hills (Malik et al. 2006; Kumar et al. 2010) except for some minor variations. Such differences may be due to variations in meteorological data like temperature, precipitation, location, soil thickness and forest age (Yang et al. 2006).

\subsection{Molecular characterization}

In the four DNA regions analysed (trnL-trnF, $p s b l-p s b \mathrm{~K}$, matK-5'trnK spacer, and ITS), we detected the sequences obtained from the present study clustered with the $C$. indica that is found in Garo hills of Meghalaya. The emergence of the DNA barcoding technique has helped in calibrating current taxonomic resolution and provided a straightforward identification system when there exist troubleshooting in morphology-based taxonomy (April et al. 2011). The CBOL plant working group proposed to use rbcL and matK as the standard DNA barcode for plants (CBOL plant working group). However, this DNA barcodebased identification of biologically complex plant groups like Citrus remains challenging due to frequent natural hybridization. So the use of intergenic spacer of chloroplast regions had been preferred for the rapid identification of other secondary citrus species (Mahadani and Ghosh 2014). The ITS region and trnL-trnF regions were successfully used to study the detailed phylogenetic and biogeography of the Zanthoxylum L. and Ivodea which belong to the Rutaceae family (Appelhans and Wen 2020; Appelhans et al. 2018). The ITS region, $t r n L-t r n F$ intergenic spacer and matK-5'trnK spacer regions were successfully used to resolve the taxonomic uncertainty of Aurantoid Rutaceae (Nguyen et al. 2019; Bayer et al. 2009). The chloroplast $p s b K-p s b /$ intergenic spacer was proven not only to be the most reliable barcode (Suzuki 
et al., 2014) but it was also useful for phylogenetic relationships analysis at the taxonomic level (Enan and Ahmed 2016). Moreover, chloroplast intergenic spacer $p s b K-p s b /$ was included as a potential candidate locus for DNA barcode because of its evolutionary rates and high capability to distinguish independently evolving beings corresponding to taxonomic species (Lahaye et al. 2008).

\subsection{Conservation}

Citrus indica is unique citrus within the true citrus species. Known for its poor regeneration and endemic nature, this citrus genotype preferred a distinct microclimate for its survival and existence. Though the presence of $C$. indica has earlier been reported from different restricted pockets in NE India, its existence and conservation cannot be ascertained in many of these locations now. After a long period, the prevalence of $C$. indica was only recently reported from Behali Reserve Forest of Assam (Dipankar et al. 2018) and thus it is scantily reported even from NE India though the region is regarded as a natural home for Citrus. An assessment of ecological conditions, habitat, and interaction with people inhabiting the locality will enable us to give a clear view for the survival of such rare and endemic citrus genotype. Apart from this, morphological data and clear molecular analysis remain essential for correct identification and further conservation efforts.

Various wild and semi-wild citrus grow in the NE India forest regions which still need to be explored for their proper identification, collection, and conservation (Sharma et al. 2004). Dailong is one such area, which is endowed with a rich biodiversity of flora and fauna. The forest consists of montane wet temperate, tropical evergreen, semi-evergreen and riparian forest. $C$. indica is one of the seven species of Indian citrus enlisted in the endangered list, which requires urgent and special consideration for conservation because of its endemic nature and also the degree of threat perception is high (Malik et al. 2006). In situ conservation seems to be the most suitable option for $C$. indica as the previous study by Malik et al. 2006 reported that the plants growing outside its habitat did not show flowering fruiting. This can be related to the complex phenomena of the lack of adaptation to the man-made environment (Zeven and de Wet 1982). Kumar et al. 2010 also observed that after propagation of $C$. indica from seeds, its growth and survival outside its natural environment became difficult. A study in Canary Island, Spain recommended reintroduction, habitat management, and protection as the most important tools for conservation and management of endangered plants (Marrero-Gómez et al. 2003). However ex situ methods of conservation are also given importance to protect the endangered species (Laskar et al. 2009). National Bureau of Plant Genetic Resources (NBPGR), Delhi has preserved the pollens and seeds of $C$. indica in Cryogene Bank for long term preservation (Malik et al. 2006). Such an initiative for ex-situ germplasm conservation of citrus can help in the rehabilitation of endangered species (Kumar et al. 2010). Cryopreservation technique and other ex situ conservation actions have been developed for longterm conservation of critically endangered species Rubus humulifolius in Finland (Edesi et al. 2020). Sharma et al. 2004 also suggested the need for more nature reserves, gene sanctuaries, and parks with the inclusion of citrus species. In Burkina Faso, the conservation strategy and survival rate of Zanthoxyllum zanthoxyloides seedlings were suggested to be managed by establishing nurseries, botanical gardens, and target places for safeguarding (Ouédraogo et al. 2019). Those sites were 
entrusted to the local communities thereby facilitating financial support for the local communities to encourage them to actively participate in the conservation of the species. Likewise, the conservation strategy for $C$. indica can also be implemented in the present study area. Moreover, any conservation strategies related to natural resources needs public education and proper awareness to the people residing in the area for maintaining a healthy environment (Kaya and Raynal 2001). Thus a holistic approach including both the ex-situ and in situ conservation methods should be developed to contribute to Citrus improvement programs (Malik et al. 2006).

Singh and Singh (2003) also stated that the anthropogenic activities are causing a serious threat to the citrus biodiversity in the NE India region for which, it has been classified as a hotspot. $C$. indica is seldom cultivated and commercialized as the fruits are small, rarely edible (Bhattaccharcharya and Dutta 1956; Tanaka 1937). The present exploration in Dailong forest area also indicated no domestication and no utility of the species known to the local tribes. It remained as ordinary wild citrus to them with no economic importance. So there was no specific conservation policy taken up in that area particularly for the citrus species. However, in the Nokrek Biosphere reserve buffer zone area, preliminary domestication and conservation measures have been taken up. $C$. indica locally known as Memang Narang in Garo language is well known to the local tribes of this region and is used for various medicinal and ritual purposes. So the local tribes had cultivated in the area (Singh 1981; Malik et al. 2006). Maybe we can assume that the species had been conserved in Garo hills but not in other parts of the NE India because of its conservation by domestication by Garo tribes. In the other parts of NE India, there are no specific uses and medicinal values known to them. Also, the Rongmei tribes of Dailong Forest have not used the part so far. They know its existence in the forest as wild form; however, there is no domestication history of the species in the place so the conservation motive is very low to the local people as domestication is one of the important ways to conserve the germplasm of species. During the survey, $C$. indica was observed to be healthy and free from any kind of disease. Such property of $C$. indica can provide rootstock of high quality for other commercial citrus varieties in the future (Malik et al. 2006). Conservation of $C$. indica was already initiated around ten decades ago in the Garo hills of Meghalaya by establishing the Citrus Gene Sanctuary which is a part of Nokrek Biosphere Reserve (Singh 1981). Likewise, the protection and rehabilitation of germplasm of the present study area should be proposed and Dailong forest should be recognized as an in situ 'Citrus Sanctuary'.

Detailed interviews with the local tribes and elders of Dailong area revealed that they have been practicing conservation activities for many generations in the form of protected sacred groves called 'Raengan'. $C$. indica was reported to be found in abundant according to the elders of Dailong village but now the plant has shrunk its population due to earlier destruction of forest for jhum cultivation. However, an initiative was taken way back in 1978 by Rongmei tribes of Dailong Village by preventing jhum cultivation and other exploitation from the forest. Further discussion was also continued with the members of Dailong Ecology \& Environment Preservation Society (DEEPS; local NGO since 1978), we came to know that they played a critical role in spreading awareness among the Rongmei tribes for forest conservation. Despite all the efforts of the local tribes to protect the forest, recent development has hampered the forest ecosystem. There are road and railway construction, and extensive illegal timber 
logging which led to the loss of large forest area and ultimately leading to the loss of rare species. Even though the local tribes are protecting the forest area, adequate conservation measures have not been implemented so far from the government or other related organizations. There is an urgent need for identifying the priority areas for protection. In southern China, priority protected areas (PPAs) planning methods have been proposed to conserve endangered and threatened plant species in the identified locations (Wang et al. 2015).

Efforts should be given in collection, characterization, and conservation of the wild and semi-wild species of citrus in NE India. The results of our present study try to give insight to develop a conservation management policy for such wild and endangered species. Future studies including these species will give deeper insights into their evolution and geographic origin. It is reported that $C$. indica is inferred to have originated from NE India region, further studies can be explored whether the ancestor species colonized which location first (likely from Nokrek, Meghalaya) followed by dispersal to other parts of other NE India. In the present study, results derived from morphology and sequence data indicated that 'Garuanthai' is identified as $C$. indica which is grown in wild habitat in Dailong forest, Manipur. The present work also supports the evidence of the origin of citrus in NE India thereby locating a new habitat of the ancestral citrus species. Both the in situ and ex situ conservation strategies should be approached to protect and conserve this species. These measures should also involve the local population by giving them proper information and awareness campaigns about the importance of habitat conservation and management to protect this precious habitat of $C$. indica.

\section{Declarations}

\section{Acknowledgments}

The villagers of Dailong granted access to the forest area and provided accommodation for the survey team. The authors extended their special thanks to Brajesh (wildlife activist and photographer) and the villager team for their help extended during the exploration trips. We also thank the Director, Institute of Bioresources and Sustainable Development, Imphal for providing financial assistance and research facilities. The IBSD communication number of the manuscript is IBSD/2020/01/027.

\section{Compliance with ethical standards}

This work does not contain any studies with human participants or animals performed by any of the authors.

\section{Informed Consent}

Informed consent was obtained from all individual participants included in the study.

\section{Declaration of competing interest}


The authors declare that they have no known competing financial interests or personal relationships that could have appeared to influence the work reported in this paper.

\section{CRediT Author contribution statement}

Elangbam Julia Devi: Conceptualization, Methodology, Investigation, Data curation, Writing - original draft. Rajendra Kumar Labala: Data curation, Bioinformatics analysis, Rakesh Sanabam:

Conceptualization, Writing - review \& editing, Nandeibam Samarjit Singh: Experimental designing, Writing - review \& editing, Rahul Modak: Writing - review \& editing, Huidrom Sunitibala Devi: Supervision, Conceptualization, Methodology, Writing - review \& editing, Project administration.

\section{Data availability statement}

The data that support the findings of this study are available from the corresponding author upon reasonable request.

\section{References}

1. Altschul SF, Thomas LM, Alejandro AS, Zhang J, Zhang Z, Miller W, Lipman DJ (1997) Gapped BLAST and PSI-BLAST: a new generation of protein database search programs. Nucleic Acids Research 25:3389-3402.

2. Appelhans MS, Reichelt N, Groppo M, Paetzold C, Wen J (2018) Phylogeny and biogeography of the pantropical genus Zanthoxylum and its closest relatives in the proto-Rutaceae group (Rutaceae). Mol. Phylogenet Evol 126:31-44.

3. Appelhans MS, Wen J (2020) Phylogenetic placement of Ivodea and biogeographic affinities of Malagasy Rutaceae. Plant Syst Evol 306:1-14. https://doi.org/10.1007/s00606-020-01633-3

4. April J, Mayden RL, Hanner RH, Bernatchez L (2011) Genetic calibration of species diversity among North America's freshwater fishes. Proc. Natl. Acad. Sci. U. S. A. 108:10602-10607. https://doi.org/10.1073/pnas.1016437108

5. Araujo EF, Queiroz LP, Machado MA (2003) What is Citrus? Taxonomic implications from a study ofcp-DNA evolution in the tribe Citreae (Rutaceae subfamily Aurantioideae). Org Divers Evol 3:55-62.

6. Bayer RJ, Mabberley DJ, Morton C, Miller CH, Sharma IK, Pfeil BE, Rich S, Hitchcock R, Sykes S (2009). A molecular phylogeny of the orange subfamily (Rutaceae: Aurantioideae) using nine cpDNA sequences. Am J Bot 96:668-685. https://doi.org/10.3732/ajb.0800341

7. Bhattacharya SC, Dutta S (1956) Classification of Citrus fruits of Assam. Sci Monogr 20. ICAR, New Delhi, p 110.

8. Borah D, Kafley P, Tangjang S, Das AP (2018) Population structure and conservation of endangered Citrus indica Yu.Tanaka (Rutaceae) in Behali Reserve Forest of Assam, India. Pleione 12:181. https://doi.org/10.26679/pleione.12.2.2018.181-186 
9. Chase W, Morton CM, Kallunki JA (1999) Phylogenetic rela- tionships of Rutaceae: a cladistic analysis of the subfami- lies using evidence from rbcL and atpB sequence variation. Am $\mathrm{J}$ Bot 8:1191-1199.

10. CBOL Plant Working Group (2009) A DNA barcode for land plants. Proc Natl Acad Sci USA, 106:12794-12797.

11. Edesi J, Tolonen J, Ruotsalainen AL, Aspi J, Häggman H ( 2020) Cryopreservation enables long-term conservation of critically endangered species Rubus humulifolius. Biodivers Conserv 29:303-314. https://doi.org/10.1007/s10531-019-01883-9

12. Enan MR, Ahmed A (2016) Cultivar-level phylogeny using chloroplast DNA barcode psbK-psbl spacers for identification of Emirati date palm (Phoenix dactylifera L.) varieties. Genet Mol Res 15. https://doi.org/10.4238/gmr.15038470

13. Federici CT, Fang DQ, Scora RW, Roose ML (1998) Phylogenetic relationships within the genus Citrus (Rutaceae) and related genera as revealed by RFLP and RAPD analysis. Theor. Appl. Genet. 96:812822. https://doi.org/10.1007/s001220050807

14. Hall T (1999) BioEdit: a user- friendly biological sequence alignment editor and analysis program for Windows 95/98/NT, in Nucliec Acids Symposium Series No 41:95-98.

15. Hodgson RW (1965) Taxonomy and nomenclature in citrus fruits. In: Krishnamurthi S (ed) Advances in agricultural sciences and their applications. Madras Agric J, Madras, pp 317-331.

16. Hynniewta M, Malik SK, Rao SR (2014) Genetic diversity and phylogenetic analysis of Citrus (L) from north-east India as revealed by meiosis, and molecular analysis of internal transcribed spacer region of rDNA. Meta Gene 2:237-251. https://doi.org/10.1016/j.mgene.2014.01.008

17. IPGRI (1999) Descriptors for Citrus. International Plant Genetic Resources Institute, Rome, Italy. ISBN 92-9043-425-2

18. Jena SN, Kumar S, Nair NK (2009) Molecular phylogeny in Indian Citrus L. (Rutaceae) inferred through PCR-RFLP and trnL-trnF sequence data of chloroplast DNA. Sci. Hortic. (Amsterdam). 119: 403-416. https://doi.org/10.1016/j.scienta.2008.08.030

19. Johnson LA, Soltis DE (1994) MatK DNA Sequences and Phylogenetic Reconstruction in Saxifragaceae s. str. Systematic Botany 19(1):143-156. doi:10.2307/2419718

20. Kaya Z, Raynal DJ (2001) Biodiversity and conservation of Turkish forests. Biol. Conserv 97:131141. https://doi.org/10.1016/S0006-3207(00)00069-0

21. Kollipara KP, Singh RJ, Hymowitz T (1997) Phylogenetic and genomic relationships in the genus Glycine Willd. based on sequences from the ITS region of nuclear rDNA. Genome 40(1):57-68. https://doi.org/10.1139/g97-008

22. Kumar S, Jena SN, Nair NK (2010). ISSR polymorphism in Indian wild orange (Citrus indica Tanaka, Rutaceae) and related wild species in North-east India. Sci Hortic (Amsterdam) 123:350-359. https://doi.org/10.1016/j.scienta.2009.10.008

23. Kumar S, Nair KN, Jena SN (2013) Molecular differentiation in Indian Citrus L. (Rutaceae) inferred from nrDNA ITS sequence analysis. Genet. Resour. Crop Evol 60:59-75. 
https://doi.org/10.1007/s10722-012-9814-x

24. Kumar S, Stecher G, Li M, Knyaz C, Tamura K (2018) MEGA X: Molecular Evolutionary Genetics Analysis across computing platforms. Molecular Biology and Evolution 3:51547-1549.

25. Kyndt T, Dung TN, Goetghebeur P, Toan HT, Gheysen, G (2010) Analysis of ITS of the rDNA to infer phylogenetic relationship among Veitnamese Citrus accessions. Genet Res Crop Evol 57:183-192

26. Lahaye R, Savolainen V, Duthoit S, Maurin O, van der Bank M (2008) A test of psbK-psbl and atpFatpH as potential plant DNA barcodes using the flora of the Kruger National Park (South Africa) as a model system. Nat. Preced. https://doi.org/10.1038/npre.2008.1896.1

27. Laskar MA, Hynniewta M, Rao CS (2009) In vitro propagation of Citrus indica Tanaka-An endangered progenitor species, Indian Journal of Biotechnology.

28. Lu Z, Zhou Z, Xie R (2011) Molecular phylogeny of the true Citrus fruit trees group (Aurantioideae, Rutaceae) as inferred from chloroplast DNA sequences. Agri Sci China 10:49-57.

29. Mahadani P, Ghosh SK (2014) Utility of indels for species-level identification of a biologically complex plant group: a study with intergenic spacer in Citrus. Mol Biol Rep 41:7217-7222. https://doi.org/10.1007/s11033-014-3606-7

30. Malik SK, Chaudhury R, Dhariwal OP, Kalia RK (2006) Collection and characterization of Citrus indica Tanaka and C. macroptera Montr.: Wild endangered species of northeastern India. Genet Resour Crop Evol 53:1485-1493. https://doi.org/10.1007/s10722-005-7468-7

31. Malik SK, Chaudhury R, Kumar S, Dhariwal OP, Bhandari DC (2012) Citrus genetic resources in India, Present status and Management. National Bureau of Plant Genetic Resources, New Delhi.

32. Marrero-Gómez MV, Bañares-Baudet A, Carqué-Alamo E (2003) Plant resource conservation planning in protected natural areas: An example Plant resource conservation planning in protected natural areas: an example from the Canary Islands, Spain. Biol Conserv 113:399-410. https://doi.org/10.1016/S0006-3207(03)00126-5

33. Morton CM, Grant M, Blackmore S (2003). Phylogenetic relationships of the Aurantioideae inferred from cpDNA sequenced data. Am J Bot 90:1463-1469.

34. Nguyen $\mathrm{CH}$, Beattie GAC, Haigh AM, Astuti IP, Mabberley DJ, Weston PH, Holford P (2019) Molecular differentiation of the Murraya paniculata Complex (Rutaceae: Aurantioideae: Aurantieae). BMC Evol. Biol. 19:1-16. https://doi.org/10.1186/s12862-019-1555-4

35. Nguyen LT, Schmidt HA, von Haeseler A, Minh BQ (2015) IQ-TREE: A fast and effective stochastic algorithm for estimating maximum-likelihood phylogenies. Molecular Biology and Evolution 32:268274.

36. Nicolosi E, Deng ZN, Gentile A, La Malfa S, Continella G, Tribulato E (2000) Citrus phylogeny and genetic origin of important species as investigated by molecular markers. Theor. Appl. Genet. 100:1155-1166. https://doi.org/10.1007/s001220051419

37. Ouédraogo L, Fuchs D, Schaefer H, Kiendrebeogo M (2019) Morphological and molecular characterization of Zanthoxylum zanthoxyloides (Rutaceae) from Burkina Faso. Plants 8. https://doi.org/10.3390/plants8090353 
38. Pessina D, Gentili R, Barcacciab G, Nicole'b S, Rossic G, Bar- bestia S, Sgorbatia S (2011) DNA content, morphometric and molecular marker analyses of Citrus limonimedica, $C$. limon and $C$. medica for the determination of their vari- ability and genetic relationships within the genus Citrus. Sci Horti 129:663-673.

39. Samuel R, Ehrendorfer F, Chase MW, Greger H (2001). Phylogenetic analyses of Aurantioideae (Rutaceae) based on non-coding plastid DNA sequences and phytochemical features. Plant Biology 3:77 - 87 .

40. Sanabam R, Somkuwar BG, Thingnam G, Moirangthem S, Handique PJ, Huidrom S (2012) CIBMAN: Database exploring Citrus biodiversity of Manipur. Bio information 8:838-840.

41. Sharma BD, Hore DK, Gupta SG (2004) Genetic resources of Citrus of north-eastern India and their potential use. Genet. Resour. Crop Evolution 51:411-418.

42. Shaw J, Lickey EB, Beck JT, Farmer SB, Liu W, Miller J, Siripun KC, Winder CT, Schilling EE, Small RL (2005) The tortoise and the hare II: Relative utility of 21 noncoding chloroplast DNA sequences for phylogenetic analysis. Am J Bot 92:142-166. https://doi.org/10.3732/ajb.92.1.142

43. Singh B (1981) Establishment of First Gene Sanctuary for Citrus in Garo Hills. Concept Publishing Company, New Delhi.

44. Singh IP, Singh S (2003) Exploration, collection and characterization of citrus germplasm-a review. Technical Bul- letin No.7, National Research Centre for Citrus, Nagpur.

45. Singh R (1967) A key of the Citrus fruits. Ind J Hortic 4:71-83.

46. Singh R, Nath N (1969) Practical approach to the classification of Citrus. In: Chapman HD (ed) Proceedings of Interna- tional Citrus Symposium, 1:435-440.

47. Suzuki JY, Matsumoto TK, Keith LM, Myers RY (2014) The chloroplast psbK-psbl intergenic region, a potential genetic marker for broad sectional relationships in anthurium. HortScience 49:1244-1252. https://doi.org/10.21273/hortsci.49.10.1244

48. Swingle WT (1943) The botany of Citrus and its wild relatives. In: Webber HJ, Batchelor DL (eds) The Citrus industry. University of California, Berkeley 1:128-474.

49. Swingle WT, Reece PC (1967) The botany of Citrus and its wild relatives in the orange subfamily. In: Reuther W, Webber HJ, Batchelor DL (eds) The Citrus industry, Uni- versity of California, Berkeley 1:190-340.

50. Taberlet P, Gielly L, Pautou G, Bouvet J (1991) Universal primers for amplification of three non-coding regions of chloroplast DNA. Plant Mol. Biol 17:1105-1109. https://doi.org/10.1007/BF00037152

51. Tanaka T (1928) On certain new Species of citrus. Studia Ci- trologica 2:155-164.

52. Tanaka T (1937) Citrus fruits of India. Allahabad Farmer 2:53-57.

53. Tanaka T (1954) Species problem in Citrus. Japanese Society for promotion of Science, Ueno, p 152.

54. Tanaka T (1977) Fundamental discussion of Citrus classifica- tion. Stud Citrol 14:1-6.

55. Wang CJ, Wan JZ, Mu XY, Zhang ZX ( 2015) Management planning for endangered plant species in priority protected areas. Biodivers Conserv 24:2383-2397. https://doi.org/10.1007/s10531-015- 
0928-2

56. White TJ, Bruns TD, Lee SB, Taylor JW (1990) Amplification and Direct Sequencing of Fungal Ribosomal RNA Genes for Phylogenetics. In: Innis.

57. Wu GA, Terol J, Ibanez V, López-García A, Pérez-Román E, Borredá C, Domingo C, Tadeo FR, Carbonell-Caballero J, Alonso R, Curk F, Du D, Ollitrault P, Roose ML, Dopazo J, Gmitter FG, Rokhsar DS, Talon M (2018) Genomics of the origin and evolution of Citrus. Nature 554:311-316. https://doi.org/10.1038/nature25447

58. Xu CJ, Bau L, Zhang B, Bei ZM, Ye XY, Zhang SL, Chen KS (2006) Parentage analysis of huyou (Citrus changshanen- sis) based on internal transcribed spacer sequences. PI Breed 125:519-522.

59. Yang J, Vázquez L, Chen X, Li H, Zhang H, Liu Z, Zhao G (2017) Development of chloroplast and nuclear DNA markers for Chinese oaks (Quercus subgenus Quercus) and assessment of their utility as DNA barcodes. Front. Plant Sci 8:816. https://doi.org/10.3389/fpls.2017.00816

60. Yang Y, Watanabe M, Li F, Zhang J, Zhang W, Zhai J (2006) Factors affecting forest growth and possible effects of climate change in the Taihang Mountains, northern China. Forestry 79:135-147. https://doi.org/10.1093/forestry/cpi062

61. Zeven AC, de Wet JMJ (1982) Dictionary of Culti- vated Plants and Their Regions of Diversity. Centre for Agricultural Publishing and Documentation, Wageningen, The Netherlands.

\section{Tables}

Table 1 Details of the sampling location and size.

\begin{tabular}{|lllll|}
\hline Co-ordinates & Spot no & Elevation & Sample size $(\mathrm{n})$ & Status \\
\hline $\mathrm{N} 25^{\circ} 00^{\prime} 22.5^{\prime \prime} \mathrm{E} 093^{\circ} 30^{\prime} 56.3^{\prime \prime}$ & 1 & $838 \mathrm{mASL}$ & 20 & Wild \\
\hline $\mathrm{N} 25^{\circ} 00^{\prime} 24.1^{\prime \prime} \mathrm{E} 093^{\circ} 31^{\prime} 13.9^{\prime \prime}$ & 2 & $951 \mathrm{mASL}$ & 10 & Wild \\
\hline $\mathrm{N} 25^{\circ} 00^{\prime} 19.1^{\prime \prime} \mathrm{E} 093^{\circ} 31^{\prime} 39.7^{\prime \prime}$ & 3 & $1115 \mathrm{mASL}$ & 12 & Wild \\
\hline
\end{tabular}

Table 2a Quantitative characters of fruit, leaf, and seed of Citrus indica 


\begin{tabular}{|llll|}
\hline Characters & Value range & Characters & Value range \\
\hline Fruit & & Leaf & \\
\hline fruit weight & $21.60-30.71 \mathrm{gm}$ & leaf lamina length & $\begin{array}{l}8.35-12.00 \\
\mathrm{~cm}\end{array}$ \\
\hline fruit diameter & $0.45-0.53 \mathrm{~cm}$ & leaf lamina width & $3.46-5.00 \mathrm{~cm}$ \\
\hline fruit length & $3.25-3.80 \mathrm{~cm}$ & petiole & $2.00-3.00 \mathrm{~cm}$ \\
\hline fruit rind thickness & $0.17-0.25 \mathrm{~cm}$ & Seed & $1.00-1.24 \mathrm{~cm}$ \\
\hline $\begin{array}{l}\text { density of oil gland per } \\
\text { cm }{ }^{2}\end{array}$ & $34.30-44.23$ & seed length & $0.78-0.80 \mathrm{~cm}$ \\
\hline diameter of fruit axis & $0.38-0.41 \mathrm{~cm}$ & seed width & $7-10$ \\
\hline number of segments & $9.00-$ & seed per fruit & 1.00 \\
\hline
\end{tabular}

Table $2 b$ Qualitative characters of fruit, leaf, and seed of Citrus indica 


\begin{tabular}{|c|c|c|c|}
\hline Characters & Value range & Characters & Value range \\
\hline Fruit & & Leaf & \\
\hline fruit shape & Obloid & leaf division & Simple \\
\hline shape of fruit base & Truncate & leaf lamina shape & $\begin{array}{l}\text { Elliptic tapering at both } \\
\text { ends }\end{array}$ \\
\hline fruit rind colour & White & $\begin{array}{l}\text { leaf lamina } \\
\text { attachment }\end{array}$ & Brevipetiolate \\
\hline shape of fruit apex & Truncate & leaf margin & Dentate \\
\hline fruit skin colour & Dark orange & leaf apex & Acuminate \\
\hline fruit axis & Solid & Vegetative life cycle & Evergreen \\
\hline fruit surface texture & Smooth & Seed & \\
\hline pulp colour & White & seed shape & Ovoid \\
\hline pulp colour intensity & Light & seed surface texture & Smooth \\
\hline nature of oil gland & Conspicuous & seed colour & Cream \\
\hline $\begin{array}{l}\text { cross section shape of } \\
\text { axis }\end{array}$ & Irregular & Cotyledon colour & Green \\
\hline style scar & Present & Chalazal spot colour & Brown \\
\hline areola & Absent & Seed embryony & Monoembryonic \\
\hline segment shape uniformity & Present & & \\
\hline Taste & Sour & & \\
\hline
\end{tabular}

Table 3 List of primer sequences used for phylogenetic analyses and PCR profile. 


\begin{tabular}{|c|c|c|c|c|}
\hline $\begin{array}{l}\text { Target } \\
\text { sequence }\end{array}$ & $\begin{array}{l}\text { Primer } \\
\text { name }\end{array}$ & $5^{\prime}-3$ 'primer sequence & References & PCR conditions \\
\hline \multirow{2}{*}{$\begin{array}{l}\operatorname{trn} L-F \\
\text { intergenic } \\
\text { spacer } \\
\text { region }\end{array}$} & c & CGA AAT CGG TAG ACG CTA CG & Taberlet et & \multirow{2}{*}{$\begin{array}{l}\text { Initial denaturation at } \\
94^{\circ} \mathrm{C} \text { for } 3 \text { min followed } \\
\text { by } 30 \text { cycles at } 94^{\circ} \mathrm{C} \text { for } \\
60 \mathrm{sec}, 48^{\circ} \mathrm{C} \text { for } 60 \mathrm{sec} \text {, } \\
72^{\circ} \mathrm{C} \text { for } 120 \text { sec and a } \\
\text { final extension at } 72^{\circ} \mathrm{C} \\
\text { for } 7 \text { min }\end{array}$} \\
\hline & $f$ & ATT TGA ACT GGT GAC ACG AG & $\begin{array}{l}\text { Taberlet et } \\
\text { al., } 1991\end{array}$ & \\
\hline \multirow{2}{*}{$\begin{array}{l}\text { ITS } \\
\text { region }\end{array}$} & ITSP4 & TCCTCCGCTTATTGATATGC & White et & \multirow{2}{*}{$\begin{array}{l}\text { Initial denaturation at } \\
94^{\circ} \mathrm{C} \text { for } 3 \text { min followed } \\
\text { by } 35 \text { cycles at } 94^{\circ} \mathrm{C} \text { for } \\
1 \text { min, } 58^{\circ} \mathrm{C} \text { for } 1 \text { min, } \\
72^{\circ} \mathrm{C} \text { for } 90 \text { sec and a } \\
\text { final extension at } 72^{\circ} \mathrm{C} \\
\text { for } 5 \text { min }\end{array}$} \\
\hline & ITSP5 & AAGTCGTAACAAGGTTTCCGTAG & $\begin{array}{l}\text { Kollipara } \\
\text { et al., } 1997\end{array}$ & \\
\hline \multirow{2}{*}{$\begin{array}{l}\text { psbl- } \\
\text { psbK } \\
\text { intergenic } \\
\text { region }\end{array}$} & psbk & TTAGCCTTTGTTTGGCAAG & Lahaye et & \multirow{2}{*}{$\begin{array}{l}\text { Initial denaturation at } \\
94^{\circ} \mathrm{C} \text { for } 5 \text { min followec } \\
\text { by } 35 \text { cycles at } 94^{\circ} \mathrm{C} \text { for } \\
30 \mathrm{sec}, 51^{\circ} \mathrm{C} \text { for } 40 \mathrm{sec} \text {, } \\
72^{\circ} \mathrm{C} \text { for } 45 \mathrm{sec} \text { and a } \\
\text { final extension at } 72^{\circ} \mathrm{C} \\
\text { for } 7 \text { min }\end{array}$} \\
\hline & psbl & AGAGTTTGAGAGTAAGCAT & $\begin{array}{l}\text { Lahaye et } \\
\text { al., } 2008\end{array}$ & \\
\hline \multirow{2}{*}{$\begin{array}{l}\text { matK-5' } \\
\text { trnK } \\
\text { spacer }\end{array}$} & matK5'R & $\begin{array}{l}\text { GCA TAA ATA TAY TCC YGA AAR } \\
\text { ATA AGT GG }\end{array}$ & $\begin{array}{l}\text { Shaw et } \\
\text { al., } 2005\end{array}$ & \multirow{2}{*}{$\begin{array}{l}30 \text { cycles of } \\
\text { denaturation }\left(94^{\circ} \mathrm{C} \text { for } 1\right. \\
\text { min), primer annealing } \\
\left(48^{\circ} \mathrm{C} \text { for } 1 \mathrm{~min}\right) \text {, } \\
\text { extension }\left(72^{\circ} \mathrm{C} \text { for } 2\right. \\
\text { min) and final extension } \\
\left(72^{\circ} \mathrm{C} \text { for } 7 \text { min }\right)\end{array}$} \\
\hline & matK6 & TGG GTT GCT AAC TCA ATG G & $\begin{array}{l}\text { Johnson } \\
\text { and Soltis, } \\
1994\end{array}$ & \\
\hline
\end{tabular}

\section{Figures}




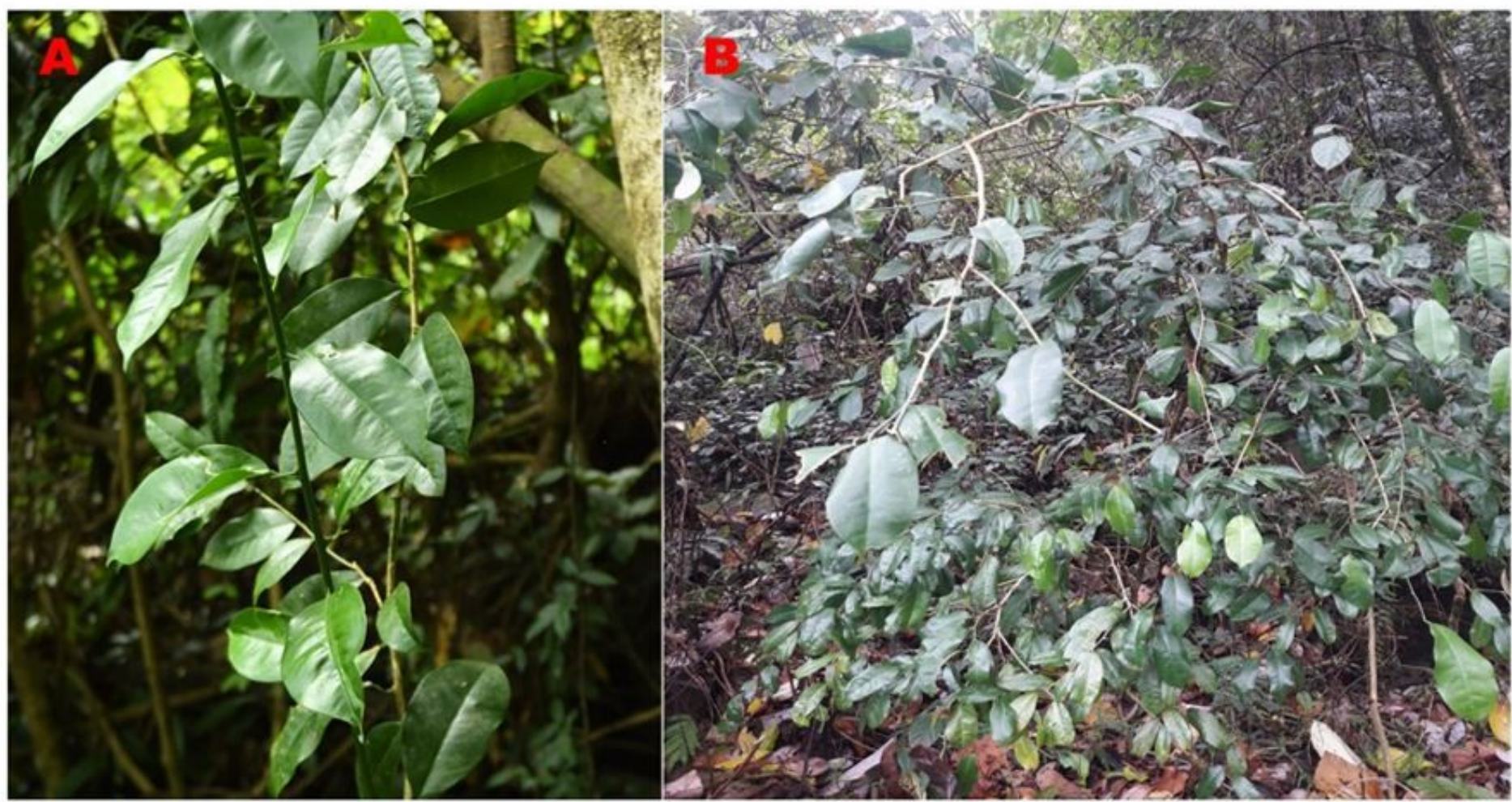

\section{Figure 1}

Citrus indica view in the surveyed area A) closed view of the plant B) whole plant view in its natural environment. 


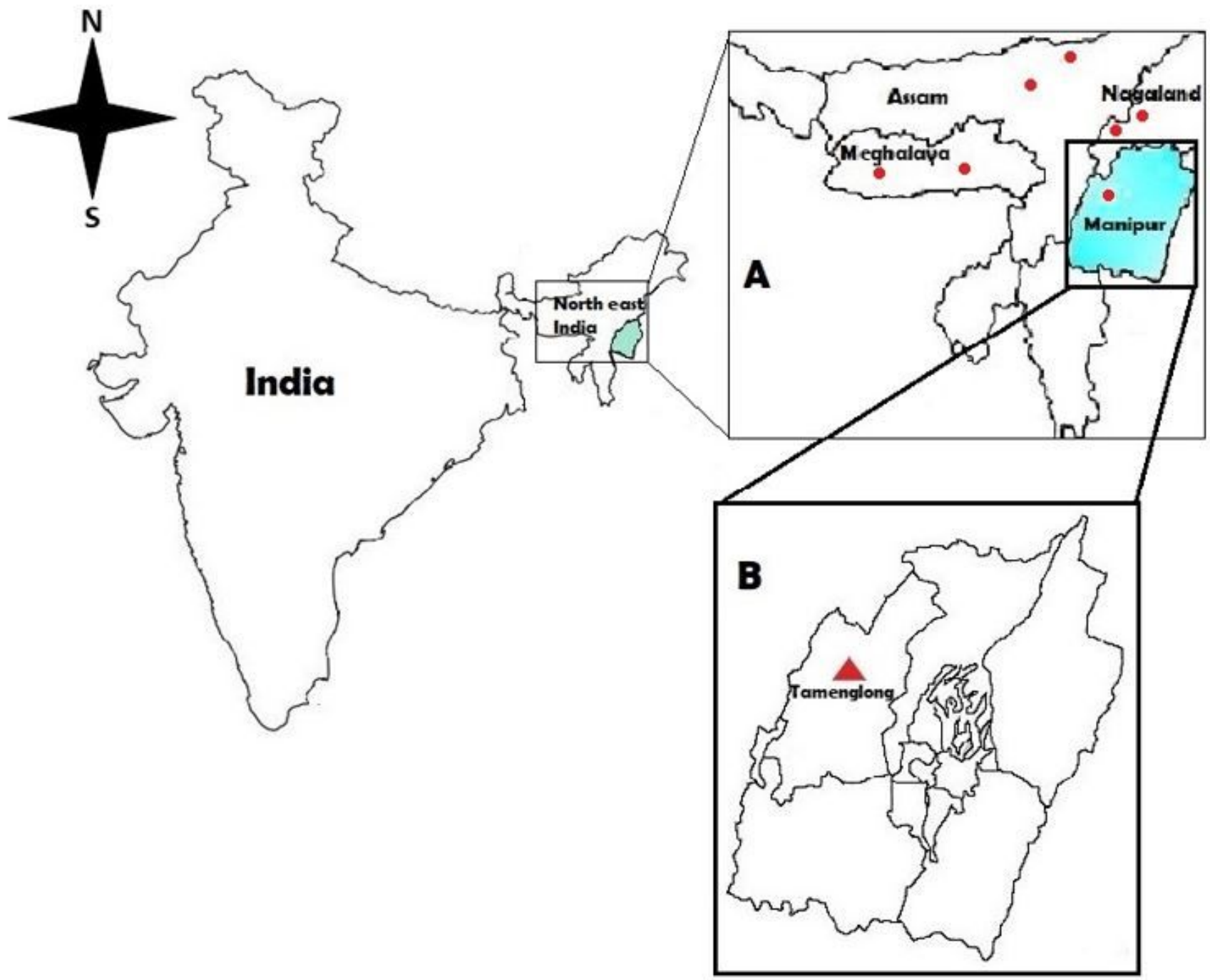

Figure 2

Locations of the Citrus indica in NE India. (A)- red circles indicate the sites from where $\mathrm{C}$. indica was reported to occur earlier (Malik et al., 2006), (B)- red triangle shows the present study site. Note: The designations employed and the presentation of the material on this map do not imply the expression of any opinion whatsoever on the part of Research Square concerning the legal status of any country, territory, city or area or of its authorities, or concerning the delimitation of its frontiers or boundaries. This map has been provided by the authors. 


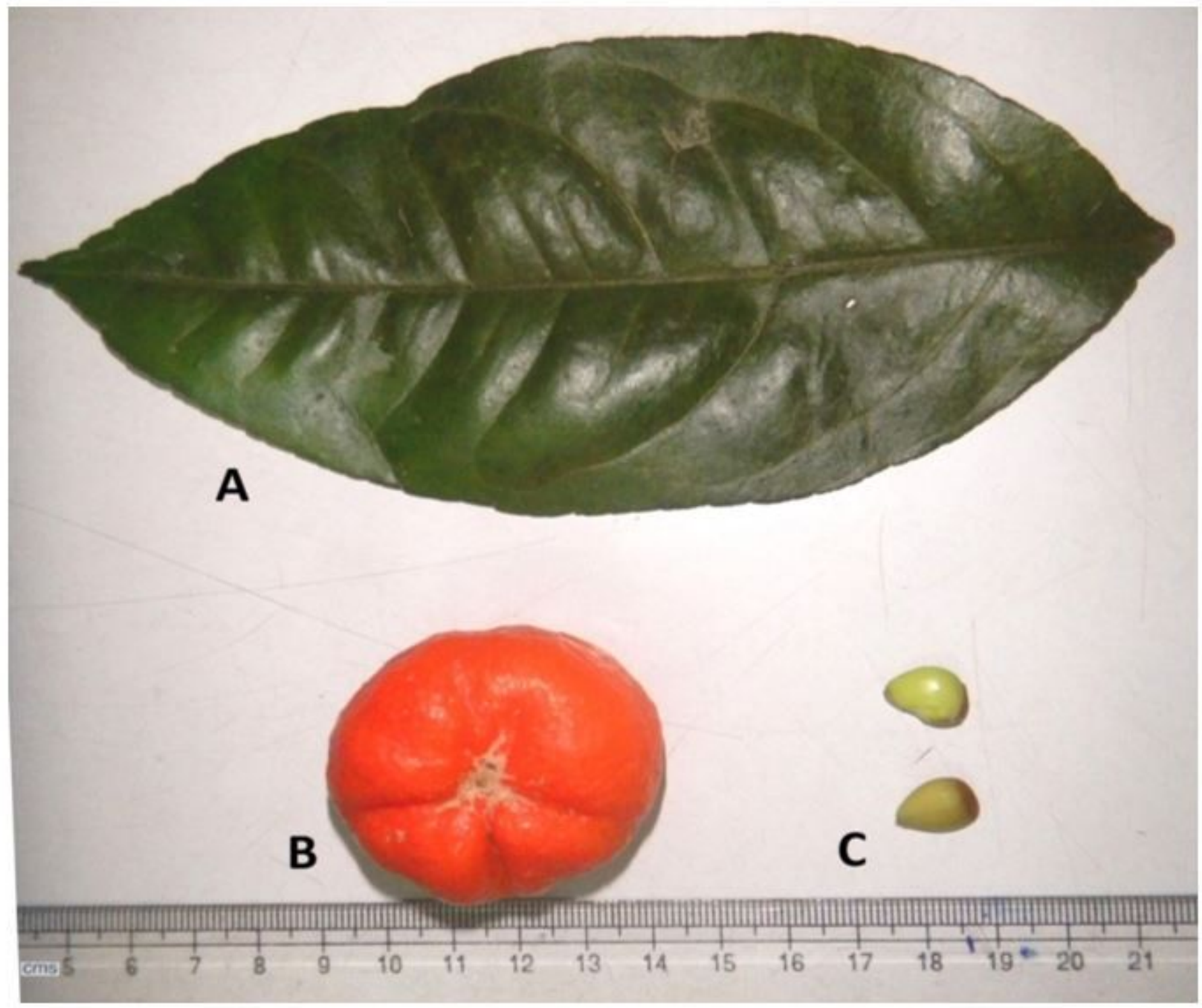

Figure 3

(A) Leaf, (B) fruit and (C) seeds of Citrus indica collected from Dailong forest, Tamenglong district, Manipur. 


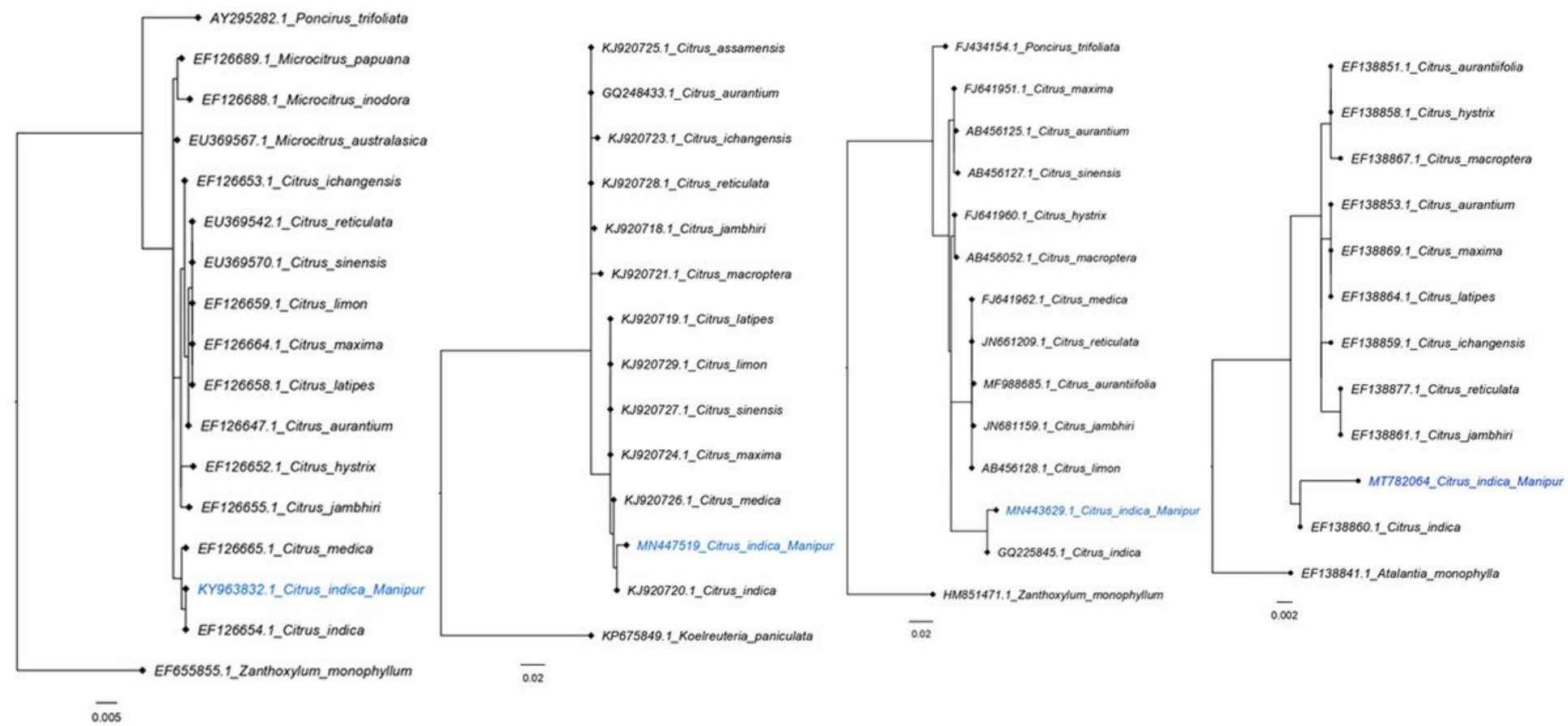

\section{Figure 4}

4a. Genetic relationship of Citrus indica (from the present study) in blue colour with other 14 citrus species and two outgroups Zanthoxylum monophyllum and Poncirus trifoliata based on partial sequences of trn L-F region. 4b. Genetic relationship of Citrus indica (from the present study)) in blue colour with other 12 citrus species and one outgroup Koelreuteria paniculata with other citrus species based on sequences of psbK-I region. 4c. Genetic relationship of Citrus indica (from the present study) in blue font with other 11 citrus species and two outgroups Zanthoxylum monophyllum and Poncirus trifoliata based on sequences of ITS region. 4d. Genetic relationship of Citrus indica (from the present study) in blue font with other 10 citrus species and one outgroup Atalantia monophylla based on sequences of matK-5'trnK spacer region.

\section{Supplementary Files}

This is a list of supplementary files associated with this preprint. Click to download.

- Supplementataryfile1.docx 